\title{
Fuel load, stand structure, and understory species composition following prescribed fire in an old-growth coast redwood (Sequoia sempervirens) forest
}

\author{
David Cowman ${ }^{1}$ and Will Russell ${ }^{2^{*}}$ (1)
}

\begin{abstract}
Background: With the prevalence of catastrophic wildfire increasing in response to widespread fire suppression and climate change, land managers have sought methods to increase the resiliency of landscapes to fire. The application of prescribed burning in ecosystems adapted to fire can reduce fuel load and fire potential while minimizing impacts to the ecosystem as a whole. Coast redwood forests have historically experienced fire from both natural and anthropogenic sources, and are likely to respond favorably to its reintroduction.

Results: Random sampling was conducted in three burned sites and in three unburned sites, in an old-growth coast redwood (Sequoia sempervirens [D. Don] Endl.) forest. Data were collected on fuel, forest structure, and understory species composition and compared between treatments. Downed woody fuel, duff depth, litter depth, and density of live woody fuels were found to be significantly lower on sites treated with fire compared to unburned sites. Density of the dominant overstory canopy species, coast redwood and Douglas-fir (Pseudotsuga menziesii var. menziesii [Mirb.] Franco), remained consistent between treatments, and the abundance of herbaceous understory plant species was not significantly altered by burning. In addition, both downed woody fuel and live fuel measures were positively correlated with time since last burn, with the lowest measures on the most recently burned sites.

Conclusions: Our results indicated that the use of prescribed burning in old-growth redwood forests can provide beneficial reductions in live and dead surface fuels with minimal impacts to overstory trees and understory herbaceous species.
\end{abstract}

Keywords: coast redwood, controlled burning, duff depth, fuel reduction, litter depth, stand composition, stand structure

\footnotetext{
* Correspondence: will.russell@sjsu.edu

${ }^{2}$ Department of Environmental Studies, San Jose State University, One

Washington Square, San Jose, California 95192, USA

Full list of author information is available at the end of the article
}

\section{Springer Open}

(c) The Author(s). 2021 Open Access This article is licensed under a Creative Commons Attribution 4.0 International License, which permits use, sharing, adaptation, distribution and reproduction in any medium or format, as long as you give appropriate credit to the original author(s) and the source, provide a link to the Creative Commons licence, and indicate if changes were made. The images or other third party material in this article are included in the article's Creative Commons licence, unless indicated otherwise in a credit line to the material. If material is not included in the article's Creative Commons licence and your intended use is not permitted by statutory regulation or exceeds the permitted use, you will need to obtain permission directly from the copyright holder. To view a copy of this licence, visit http://creativecommons.org/licenses/by/4.0/. 


\section{Resumen}

Antecedentes: Ante la prevalencia de fuegos catastróficos incrementándose en respuesta a la prolongada supresión de incendios y al cambio climático, los gestores de recursos han buscado métodos para incrementar la resiliencia de los paisajes al fuego. La aplicación de quemas prescriptas en ecosistemas adaptados al fuego puede reducir la carga de combustibles y el potencial de incendios, mientras se minimizan los impactos del ecosistema como un todo. Los bosques costeros de sequoias han experimentado fuegos históricos de origen tanto humano como naturales y es probable que respondan favorablemente a su reintroducción.

Resultados: Un muestreo al azar fue conducido en tres sitios quemados y en tres no quemados, en un bosque maduro de sequoias costeras (Sequoia sempervirens [D. Don] Endl.). Los datos colectados fueron sobre combustibles, estructura del bosque, y composición de especies del sotobosque, y comparados entre tratamientos. El combustible leñoso caído, la profundidad de la capa de combustible leñoso orgánico, la profundidad de la broza, y la densidad de combustibles leñosos vivos fue menor sobre sitios tratados con fuego que en los no tratados. La densidad de las especies dominantes del dosel, la sequoia costera y el abeto de Douglas (Pseudotsuga menziesii var. menziesii [Mirb.] Franco), permanecieron consistentes entre tratamientos y la abundancia de herbáceas del sotobosque no fue alterada por las quemas. Adicionalmente, tanto el combustible leñoso orgánico caído y la medición del combustible leñoso vivo estuvieron positivamente correlacionados con el tiempo desde la última quema, con los menores valores medidos en los sitos más recientemente quemados.

Conclusiones: Nuestros resultados indican que la aplicación de quemas prescriptas en bosques maduros de sequoias costeras puede proveer de reducciones beneficiosas en combustibles vivos y muertos superficiales, con un mínimo impacto en árboles del dosel superior y en las especies herbáceas del sotobosque.

\section{Abbreviations}

BBRSP: Big Basin Redwoods State Park

DBH: Diameter at Breast Height

JREB: Johansen Road (East) prescribed burn project (Burned)

NERU: North Escape Road sample site (Unburned)

OVSB: Ocean View Summit prescribed burn project (Burned)

SUNU: SUNset trail sample site (Unburned)

S2SB: Skyline to (2) the Sea prescribed burn project (Burned)

S2SU: Skyline to (2) the Sea prescribed burn project (Unburned)

\section{Background}

The nature of fire in the coast redwood (Sequoia sempervirens [D. Don] Endl.) forest is complex and unpredictable due to topographic variation, complex weather patterns, and an evolving regime of anthropogenic disturbance (Varner and Jules 2017). Occurring in coastal regions with frequent maritime fog during the dry season, and relatively low lightning storm activity during the dry season, naturally occurring fires in S. sempervirens forests have been historically low compared to many other forest types in California (Keeley 2005). With human settlement in the region, the majority of fires became anthropogenic in origin (McBride 1983). Indigenous burning generally resulted in low-intensity surface fires, with higher frequencies occurring in close proximity to grasslands, oak (Quercus L.) woodlands, and indigenous settlements (Greenlee and Langenheim 1990; Stephens and Fry 2005; Lorimer et al. 2009; Jones and Russell 2015). Over time, the frequency and seasonality of fire has changed with cultural land use practices (Stuart 1987; Greenlee and Langenheim 1990). Initially, fire frequency remained relatively high following European settlement, but a shift in fire policy in the early twentieth century led to a dramatic decline in the occurrence of fire as a result of institutional fire suppression. Concern over the effects of a century of fire suppression on fuel load and forest composition has led managers to consider introducing controlled burning to coast redwood forests in an effort to mimic the low-intensity fire regime of the indigenous period (Stuart 1987; Keeley 2002).

Sequoia sempervirens maintains a host of adaptations to fire, including prolific vegetative sprouting, thick fibrous bark, and a high canopy (Barbour et al. 2001; Varner et al. 2017; Stephens et al. 2018), that allows canopy to be retained, or quickly reestablished, after fire (Lazzeri-Aerts and Russell 2014). As a result, plant species associated with Sequoia sempervirens are generally dependent on closed-canopy conditions, but also exhibit some adaptions to fire (Busing and Fujimori 2002). Sequoia sempervirens has a competitive advantage over associated tree species following fire, in part because of prolific post-fire reproduction (Lazzeri-Aerts and Russell 2014). In addition, largerdiameter trees $(>30 \mathrm{~cm}$ diameter at breast height $[\mathrm{DBH}])$ retain lower mortality rates than smallerdiameter trees following fire (Lazzeri-Aerts and 
Russell 2014; Engber et al. 2017), due in part to thicker bark and increased canopy height with age (Barbour et al. 2001). However, changes to the fire regime can result in shifts in species dominance (relative cover of individual species divided by total cover of all species), which in turn can affect fuel beds and thus fire behavior, timing, and intensity (Mack and D'Antonio 1998; D'Antonio and Vitousek 1992; Brooks et al. 2004; Metz et al. 2013).

The three basic factors that influence fire behavior are fuel, weather, and topography (Biswell 1989). Weather and topography are largely unmanageable; thus, fuel reduction and vegetation management are used by land managers to mitigate high-intensity wildfires. Due to its' massive size and long-lived nature, S. sempervirens produces the largest fuel load of any ecosystem type ever recorded, with some studies estimating total fuel load between 252 and $619 \mathrm{Mg} \mathrm{ha}^{-1}$ (Busing and Fujimori 2002; Norman et al. 2009). However, total fuel load may not be the most useful factor in predicting fire severity. Factors that influence fire behavior include fuel bed depth, litter depth, duff depth, density of juvenile seedlings and sprouts, as well as receptive fuel bed moisture content (Keyes and Varner 2006). Fuel type and continuity, both vertical and horizontal, help dictate a fire's rate of spread and intensity. Continuous fine woody fuels $(<7.6 \mathrm{~cm}$ diameter) allow fire to ignite and spread rapidly, whereas a high load of coarse woody fuels $(>7.6 \mathrm{~cm}$ diameter) are slower to ignite but will continue to burn longer and generate more energy (Biswell 1989).

As a means of modifying potential fire behavior within the S. sempervirens ecosystem, land managers have employed several methods including variable density thinning, strategically situated shaded fuel breaks, and prescribed fire. A host of impacts are associated with the use of silvicultural treatments in the S. sempervirens forest type, however (Loya and Jules 2008; Russell and Michels 2010; Hanover and Russell 2018). And although fuel structure in S. sempervirens forest has been well described (Finney and Martin 1993), there is little available research on the impacts of prescribed fire on fuels and associated plant communities. Goals of prescribed burning can include the reduction of fuel load (including live and downed woody material), consumption of receptive fuel beds, reduction in juvenile and hardwood stems, and disruption of horizontal fuel continuity and vertical fuel arrangement (Biswell 1989).

The purpose of this study was to quantify the effects of prescribed burning in the $S$. sempervirens understory in regard to fuel load, forest stand composition, structure, and understory species assemblage. While the impacts of fire suppression continue to compound, and frequency and intensity of wildfires increases, a renewed focus has been placed on the fire prevention and fuel manipulation phase of forest management, with impacts to understory plant species and overall forest health increasingly becoming a secondary concern.

\section{Methods}

\section{Study sites}

Big Basin Redwoods State Park (BBRSP) is the oldest state park in California, USA, located approximately $37 \mathrm{~km}$ northwest of the city of Santa Cruz, in the Santa Cruz Mountains. The Park rests in two county jurisdictions: Santa Cruz and San Mateo counties. The majority of BBRSP was set aside in 1902 via the passing of a 1901 State bill creating California Redwood Park. In 1927, California Redwood Park was renamed Big Basin Redwoods State Park. A total of 3110 hectares were set aside in the initial creation of the Park to protect old-growth $S$. sempervirens stands from the rapid expansion of logging operations. In 1916, an additional $\sim 1532$ hectares were added to the Park, including the lands described in this project.

Big Basin Redwoods State Park is in the southern end of the Marine West Coast Climatic Zone (Martin 1998). To the south and east of the Park lies the Mediterranean Climatic Zone, which heavily influences the climate of the Park as well. Due to its proximity to the coast and maritime influence, BBRSP does not experience extreme seasonal changes and exhibits high relative humidity and consistent temperatures throughout much of the year (Martin 1998).

Elevation within BBRSP ranges from sea level in the western portion of the Park to just over $600 \mathrm{~m}$; however, the portion of the Park composed of primarily old-growth S. sempervirens ranges from approximately 300 to $600 \mathrm{~m}$ in elevation. The majority of the roughly 10800 ha of oldgrowth $S$. sempervirens resides on the eastern portion of the Park, near Park headquarters.

Three sample sites were selected in each of two treatments (burned and unburned). Data retrieved from the California Department of Parks and Recreation (California State Parks) regarding prescribed fire plot boundaries and areas of old-growth $S$. sempervirens were utilized to select plot locations on maps created on ArcGIS.

The burned sites represented three previous prescribedfire burn sites, most recently experiencing fire in 1999, 2007, and 2011 (Table 1, Fig. 1). Sampling occurred on sites of similar biotic and abiotic conditions. The prescribed-fire sites included the Ocean View Summit Project (OVSB), Upper Skyline to the Sea Project (S2SB), and the Johansen Road East Project (JREB) (Table 1). The unburned sample sites included the Skyline to the Sea Project (S2SU), the North Escape Road site (NERU), and 
Table 1 Sample site descriptions and characteristics for areas treated with prescribed fire, as well as untreated controls, in Big Basin Redwoods State Park, California, USA. Data were collected in 2019 to determine the influence of burns conducted between 1999 and 2011 on vegetation, forest structure, and fuel load. Sites include: Ocean View Summit (OVSB), Skyline to the Sea burned (S2SB), Johansen Road East (JREB), Sunset Trail (SUNU), Skyline to the Sea unburned (S2SU), North Escape Road (NERU). Lowest RH = lowest humidity recorded on burn days; Highest $\mathrm{RH}=$ highest humidity recorded on burn days

\begin{tabular}{|c|c|c|c|c|c|c|}
\hline & \multicolumn{3}{|c|}{ Prescribed-burned sample sites } & \multicolumn{3}{|c|}{ Unburned sample sites } \\
\hline & OVSB & S2SB & JREB & SUNU & S2SU & NERU \\
\hline Year burned & 1999 & 2007 & 2011 & NA & NA & NA \\
\hline Area burned (ha) & $\sim 109$ & 146.2 & 206.7 & NA & NA & NA \\
\hline Elevation range $(\mathrm{m})$ & 410 to 472 & 304 to 439 & 413 to 492 & 259 to 340 & 357 to 425 & 307 to 360 \\
\hline Mean aspect $\left({ }^{\circ}\right)$ & 142 & 237 & 241 & 240 & 265 & 144 \\
\hline Slope range (\%) & 0 to 51 & 12 to 65 & 16 to 62 & 14 to 49 & 11 to 55 & 5 to 40 \\
\hline Ignition dates & $\begin{array}{l}2 \text { Nov } 1999 \text { to } \\
8 \text { Jan } 2000\end{array}$ & $\begin{array}{l}9 \text { to } 24 \mathrm{Nov} \\
\text { and Jan } 2007\end{array}$ & $\begin{array}{l}19 \text { Oct } 2011 \text { to } \\
4 \text { Nov } 2011\end{array}$ & NA & NA & NA \\
\hline Lowest RH (\%) & 35 & 37 & 12 & NA & NA & NA \\
\hline Highest RH (\%) & 100 & 100 & 100 & NA & NA & NA \\
\hline Fire activity & $\begin{array}{l}\text { Slow backing fire } \\
\text { with intermittent runs. }\end{array}$ & $\begin{array}{l}\text { Backing fire with } \\
\text { intermittent runs } \\
\text { and torching. }\end{array}$ & $\begin{array}{l}\text { Backing fire with intermittent } \\
\text { runs and torching. } 0.4 \text { ha slop-over }\end{array}$ & NA & NA & NA \\
\hline
\end{tabular}

finally the Sunset Trail site (SUNU). For all sample sites, the last letter of the acronym refers to "burned" or "unburned" treatments" "B" for sites that had received prescribed burning or " $U$ " for sites that were unburned by prescribed fire. It should be noted that all sites experienced the same wildfire in 1936, so that the time since the last burn for OVSB at the time of analysis was $20 \mathrm{yr}$, for S2SB was $12 \mathrm{yr}$, for JREB was $7 \mathrm{yr}$, and $83 \mathrm{yr}$ for all unburned sites. Although all of the sampled locations had slight variations in topographic and microclimatic conditions, they had similar overstory dominance, plant community composition, seasonal moisture levels, and soil types (loam or sandy loam), allowing credible comparisons regarding fire effects on ecosystem composition (Table 1). Additionally, information on prescribed-fire operations was limited and represents a compilation of handwritten and typed notes from spot weather forecasts on burn days (OVSB and S2SB), conversations with fire managers on site, and Department of Parks and Recreation daily records of weather (JREB). Ideal conditions for burns were described in prescribed-burn plans for the three projects. Plans called for a relative humidity of 25 to 89\%, air temperature of 45 to 75 degrees Fahrenheit, wind speed of 0 to $16 \mathrm{~km} \mathrm{~h}^{-1}$, and a 10-hour deadfuel moisture of 8 to $14 \%$ for ignitions to commence. Additionally, primary ignitions were only permitted if at least $3.81 \mathrm{~cm}$ of precipitation had fallen during the rainy season, or $2.54 \mathrm{~cm}$ if no rain had fallen prior to 1 November. Additionally, ignition patterns for the three burns typically began with perimeter ignitions along ridgetops, followed by flanking and interior strip ignition. In poor burn environments, when dead-fuel moisture was too high, ignitions were limited to large accumulations of fuel, or "jackpots." Finally, limited ignitions by helicopter were attempted for the JREB plot.

\section{Sample design}

Sampling was conducted using 20 randomly selected $10 \mathrm{~m}$ diameter circular plots in each of the three sites that experienced controlled burning, and $2010 \mathrm{~m}$ diameter plots randomly selected in ecologically similar unburned sites (Lazzeri-Aerts and Russell 2014; Scherer et al. 2016; Hanover and Russell 2018). Ten-meter diameter plots were chosen because they were large enough to capture tree density and were small enough to be manageable for meticulous measurements of juvenile tree species density (Reid and Thompson 1996; Brower et al. 1998). A minimum sample size of 20 plots per site was employed, based on a power analysis conducted in similar S. sempervirensdominated old-growth forest utilizing stand density and species richness as variables (Russell and Michels 2010). This resulted in a total of 120 sampled plots: 60 from areas that experienced prescribed fire, and 60 from areas that did not experience prescribed fire. All plots were located at least $10 \mathrm{~m}$ from adjacent plots, $10 \mathrm{~m}$ from special habitat types (i.e., riparian or rocky outcroppings), and approximately $200 \mathrm{~m}$ from paved roads, to avoid edge effects on sampled areas (Jones and Russell 2001; Russell and Michels 2010). All trees with $50 \%$ or more basal area within plot delineation boundaries were inventoried and measured. Each plot was further broken down into four quadrants in order to make ocular estimates of ground cover more accurate. 


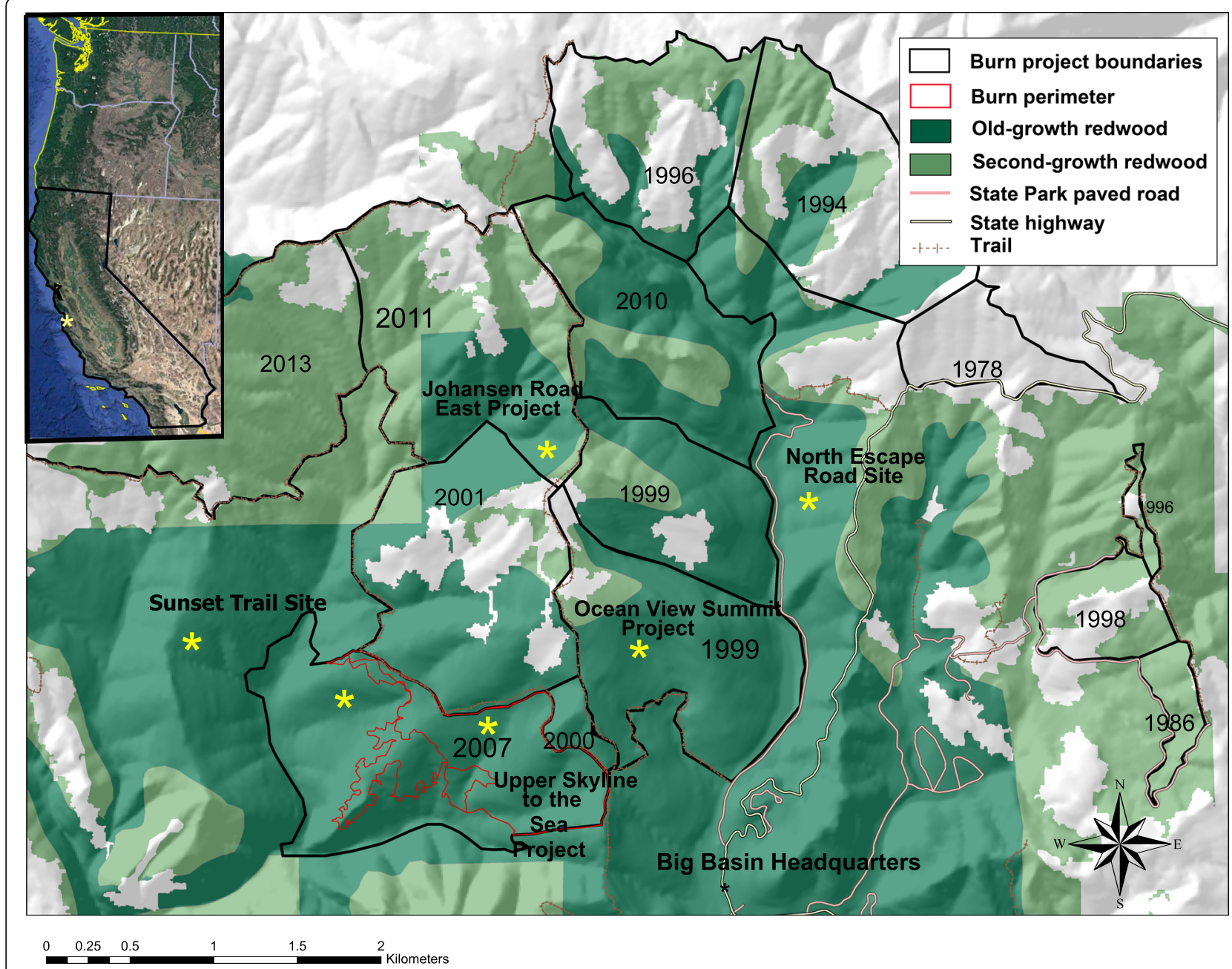

Fig. 1 Prescribed burn project boundaries in Big Basin Redwoods State Park, Boulder Creek, California, USA. Data were collected in 2019 to determine the influence of burns conducted between 1999 and 2011 on vegetation, forest structure, and fuel load. Yellow stars approximate sample site locations. Listed years and names represent previous prescribed fire sites. Data provided by California State Parks

\section{Field sampling}

Sampling occurred during the summer of 2019. Slope, aspect, elevation, and canopy cover were recorded at plot center, in addition to GPS coordinates using a Garmin Etrex 20 GPS unit (Garmin Ltd., Olathe, Kansas, USA). In order to determine percent canopy cover within each plot, a convex spherical densiometer was used from plot center, and readings were taken in each cardinal direction (Korhonen et al. 2006). Total woody and herbaceous cover and dominance was determined using ocular estimates in the four subdivided quadrants within the plot, resulting in a percent cover for each species. The percent-cover values from the four quadrants were then averaged for a plot-level cover estimate. Unknown species were collected and identified using the The Jepson Manual (Baldwin et al. 2012).

Each tree with at least $50 \%$ of its basal area within the plot boundary and greater than $10 \mathrm{~cm} \mathrm{DBH}$ was identified to species. Diameter at breast height (DBH) was taken $1.4 \mathrm{~m}$ from the ground surface along the uphill side of the tree. Trees with multiple stems were considered separate if the point of separation occurred below $1.4 \mathrm{~m}$ from the soil surface. Trees less than $10 \mathrm{~cm}$ DBH were counted, identified, and recorded separately into seedlings and sprouts, and sapling delineations $(<1$ $\mathrm{m}$ in height and $>1 \mathrm{~m}$ in height, respectively). Trees were recorded as either live or dead; burned trees with any residual growth or sprouting were considered live (Lazzeri-Aerts and Russell 2014).

To assess dead and downed woody fuel load within the burn sites, the planar intersect technique provided in Brown (1974) was utilized. Two transect lines were sampled from the plot center of each $10 \mathrm{~m}$ diameter plot with the first extending $11.34 \mathrm{~m}$ along the dominant slope of the plot, and the second extending 90 degrees from the first transect line in the clockwise direction. 
For fuel load assessments, the $10 \mathrm{~m}$ diameter plots only served to determine the beginning point for transect lines. All woody fuels intersecting the transect plane up to $1.52 \mathrm{~m}$ vertically were tallied or measured by size class, including fuel depth (defined as dead material measured from its highest point to the top of the litter layer, litter (defined as fresh needles, leaves, twigs, and cones measured to the top of the duff layer); and duff (defined as partially decomposed organic material measured from the bottom of the litter layer to the mineral soil). Fuels intersecting the transect line and extending vertically $1.83 \mathrm{~m}$ were broken down into predetermined size classes that represented 1-hour (0 to $0.64 \mathrm{~cm}), 10$-hour $(6.4$ to $2.54 \mathrm{~cm}), 100$-hour $(2.54$ to $7.62 \mathrm{~cm})$, and $\geq 1000$-hour $(\geq 7.6 \mathrm{~cm}$ ) fuels (Brown 1974).

\section{Data analysis}

Fine and coarse woody fuels were analyzed using calculations detailed in Brown (1974) to attain mean fuel load in tons per acre and then converted to metric tons per hectare $\left(\mathrm{Mg} \mathrm{ha}^{-1}\right)$ for each time-lag class (1-hour, 10-hour, 100-hour, and $\geq 1000$-hour). Calculations were made for each individual transect and then averaged across burn sites. In addition, fuel load estimates were made for the total of each sample site, combining transect lengths per sample site. Calculations for fine woody fuels (1-hour, 10-hour, and 100-hour,) were determined using Equation 1, provided by Brown (1974):

$$
\text { Fine Woody Fuel Load }\left(\mathrm{Mg} \mathrm{ha}^{-1}\right)=\frac{k n d^{2} s_{\mathrm{oc}} a c}{N l} \text {, }
$$

where $k$ is a constant of 11.64 (Brown 1974), $n$ represents the number of individual particles counted in each size class per transect, $d^{2}$ is the square of the quadratic mean diameter of each size class, $s_{\mathrm{oc}}$ is the composite specific gravity, $a$ is the composite angle correction factor for each size class, $c$ is the average transect slope correction factor, and $N l$ is the transect length. The slope correction factor $(c)$ for each individual transect line estimate was dependent upon the slope of that transect line (\%), and was calculated using Equation 2:

$$
c=\sqrt{1+\left(\frac{\text { percent slope }}{100}\right)^{2}}
$$

For composite transect line calculations yielding a single fuel load estimate per sample site, the mean slope correction factor was utilized. For all other constant values $\left(d^{2}, a\right.$, and $\left.s_{\text {oc }}\right)$, values found in Brown (1974) were used for non-slash, conifer, and Western species.

Fuel load for $\geq 1000$-hour fuels $(\geq 7.62 \mathrm{~cm})$ were calculated using Equation 3 from Brown (1974):
Coarse Woody Fuel Load $\left(\mathrm{Mg} \mathrm{ha}^{-1}\right)=\frac{k\left(\sum d^{2}\right) \mathrm{s}_{\mathrm{oc}} a c}{N l}$,

where all variables mentioned above are the same and $\Sigma d^{2}$ is the sum of the diameters of fuel particles (sound and rotten) squared (Brown 1974). Thousand-hour sound and rotten calculations were made separately and then combined into a single value. For all diameter estimates, measurements were made in inches and used to calculate fuel loading in tons per acre and later converted into metric tons per hectare $\left(\mathrm{Mg} \mathrm{ha}^{-1}\right)$.

Statistical analyses were performed using $\mathrm{R}$ software version 3.4.3 (R Development Core Team 2017), with an $\alpha$ level of 0.05 used to determine statistical significance for all statistical analyses. Dependent variables, including duff depth, litter depth, fuel depth, canopy cover, fuel load, understory cover, and stand density, were tested for normality and homogeneity of variances using Shapiro Wilk's (Srivastava and Hui 1987) and Fligner Killeen's (Fligner and Killeen 1976) tests, respectively. Spearman rank order correlations were used to determine correlational relationships between dependent variables with time since burn (McCune and Grace 2002). Nested analysis of variance tests (ANOVA), with the nlme package in $\mathrm{R}$, were used for variables averaged at the unit level to assess differences between burned and unburned treatments, with sample site considered as a random mixed effect (Laird and Bates 1988). To assess differences in stand structure of mature canopy trees, all stems greater than $10 \mathrm{~cm}$ DBH were separated into six predetermined size classes ( 10 to $24 \mathrm{~cm}, 25$ to $49 \mathrm{~cm}, 50$ to $99 \mathrm{~cm}, 100$ to $149 \mathrm{~cm}, 150$ to $199 \mathrm{~cm}$, and $200+\mathrm{cm}$ ).

\section{Results}

Spearman rank order tests indicated correlations between the time since the last fire and several fuel load metrics including duff depth, litter depth, coarse woody fuel load $\left(>7.6 \mathrm{~cm}\right.$ diameter, $\left.\mathrm{Mg} \mathrm{ha}^{-1}\right)$, and 1-hour fuel load $\left(\mathrm{Mg} \mathrm{ha}^{-1}\right)$ (Table 2, Fig. 2).

Coarse woody fuel load, duff depth, and litter depth were all found to be significantly lower in burned versus unburned treatments, with duff depth $49.8 \%$ lower, litter depth $11.85 \%$ lower, and coarse woody fuels $41.31 \%$ lower. However, no statistical differences were noted for fine woody fuels or fuel depth (Table 3).

\section{Stand composition and structure}

Spearman's coefficient tests indicated a positive correlation between time since fire and total stand density, density of sapling-sized stems $(<10 \mathrm{~cm} \mathrm{DBH},>1 \mathrm{~m}$ height), and the density and relative basal dominance of Notholithocarpos densiflorus (Hook. \& Arn.) Manos, Cannon \& S. H. Oh (Table 2). The combined density of mature-sized trees $(>10$ $\mathrm{cm} \mathrm{DBH}$ ) was lower on burned versus unburned plots 
Table 2 Spearman rank order correlation values (Rho) for dependent variables with time since fire. Analyses were performed on six sample sites, representing four times since burn. Times since burn include 7 yr, 12 yr, 20 yr, and 83 yr, in Big Basin Redwoods State Park, Boulder Creek, California, USA. Data were collected in 2019 to determine the influence of burns conducted between 1999 and 2011 on vegetation, forest structure, and fuel load

\begin{tabular}{|c|c|c|}
\hline Variable & $P$ & Rho \\
\hline Duff depth (cm) & $<0.0010$ & 0.60 \\
\hline Litter depth $(\mathrm{cm})$ & $<0.0010$ & 0.19 \\
\hline Fuel depth (cm) & 0.33 & -0.045 \\
\hline Coarse woody fuel load $\left(>7.6 \mathrm{~cm}\right.$ diameter, $\mathrm{Mg} \mathrm{ha}^{-1}$ ) & 0.014 & 0.15 \\
\hline Fine woody fuel load $\left(<7.6 \mathrm{~cm}\right.$ diameter, $\left.\mathrm{Mg} \mathrm{ha}^{-1}\right)$ & 0.94 & 0.0052 \\
\hline 1-hour fuel load (Mg ha $\left.{ }^{-1}\right)$ & $<0.0010$ & 0.40 \\
\hline 10-hour fuel load $\left(\mathrm{Mg} \mathrm{ha}^{-1}\right)$ & 0.20 & 0.084 \\
\hline 100-hour fuel load (Mg ha $\left.{ }^{-1}\right)$ & 0.30 & -0.067 \\
\hline Canopy cover (\%) & 0.0020 & 0.28 \\
\hline Sequoia sempervirens stand density $\left(\right.$ stems ha ${ }^{-1}$ ) & 0.94 & -0.010 \\
\hline Notholithocarpos densiflorus stand density (stems ha ${ }^{-1}$ ) & 0.0020 & 0.29 \\
\hline Total stand density $\left(\right.$ stems ha ${ }^{-1}$ ) & 0.013 & 0.23 \\
\hline Sequoia sempervirens relative basal dominance (\%) & 0.12 & -0.14 \\
\hline Notholithocarpos densiflorus relative basal dominance (\%) & 0.0090 & 0.24 \\
\hline Total basal area $\left(\mathrm{m}^{2} \mathrm{ha}^{-1}\right)$ & 0.85 & -0.020 \\
\hline Density of stems $<10 \mathrm{~cm} \mathrm{DBH}$ and $<1 \mathrm{~m}$ in height (stems ha ${ }^{-1}$ ) & 0.15 & 0.13 \\
\hline Density of stems $<10 \mathrm{~cm} \mathrm{DBH}$ and $>1 \mathrm{~m}$ in height (stems ha ${ }^{-1}$ ) & $<0.0010$ & 0.52 \\
\hline Understory species richness per plot (number of species) & 0.35 & -0.090 \\
\hline Understory cover per plot (\%) & 0.36 & -0.080 \\
\hline Shrub species richness per plot (number of species) & 0.0060 & 0.25 \\
\hline Shrub cover per plot (\%) & $<0.0010$ & 0.34 \\
\hline
\end{tabular}

(Table 4), with the majority of this variation occurring in regard to $N$. densiflorus. Similarly, combined juvenile stem density $(<10 \mathrm{~cm}$ DBH) was lower on burned sites, with the majority of variation found for $N$. densiflorus, with no significant differences found for the other species present.

Nested ANOVA tests comparing individual size class density between treatments indicated no significant differences for any size class with regard to S. sempervirens or Pseudotsuga menziesii var. menziesii [Mirb.] Franco. However, tests comparing $N$. densiflorus stand density by size class between the two treatments indicated significant differences in both the juvenile size classes (seedling and sprout, and sapling), as well as the 10 to $24 \mathrm{~cm}$ and 25 to $49 \mathrm{~cm}$ size classes (Fig. 3). The largest difference was in density of $N$. densiflorus saplings, resulting in a visible difference in subcanopy ladder fuels between treatments (Fig. 4).

Mean percent canopy cover varied between burned and unburned treatments $(F=16.75, P<0.001, \mathrm{df}=$ $1)$; with a mean percent canopy cover of $91.43 \pm 0.51$ (SE) on burned sites compared to $93.92 \pm 0.34 \%$ on unburned sites

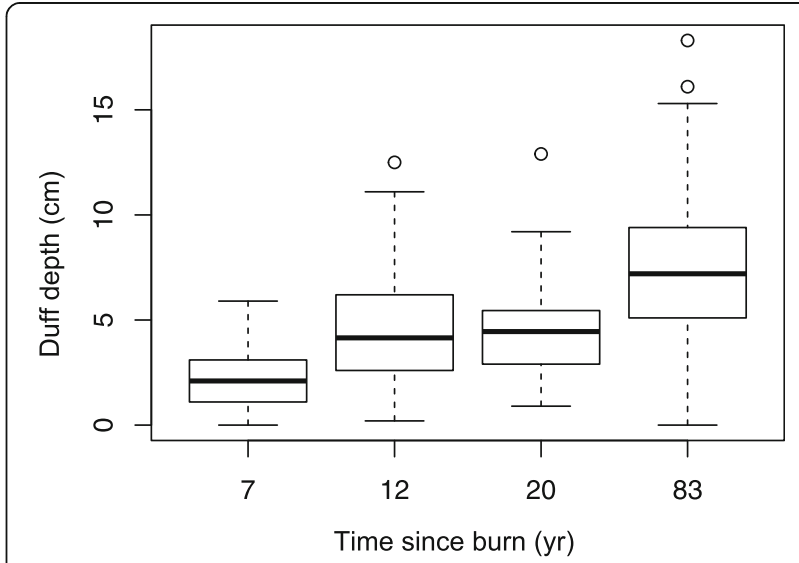

Fig. 2 Boxplots and stripchart of duff depth (cm) differences with time since burn (yr) for six sample sites in Big Basin Redwoods State Park, Boulder Creek, California, USA. Data were collected in 2019 to determine the influence of burns conducted between 1999 and 2011 on vegetation, forest structure, and fuel load. Times since burn $7 \mathrm{yr}, 12$ yr, and $20 \mathrm{yr}$ represent sites that were burned in 1999, 2007, and $2011-$ 2012, respectively. Time since burn 83 yr represents three reference sample sites that were most recently burned in a wildfire in 1936 . Boxes represent the upper and lower quartiles, whiskers represent full range of data excluding outliers, circles represent outliers 
Table 3 Comparison of receptive fuel bed and fine woody fue (FWF; $<7.6 \mathrm{~cm}$ diameter) and coarse woody fuel (CWF; $>7.6 \mathrm{~cm}$ diameter) loading between burned and unburned plots in Big Basin Redwoods State Park, Boulder Creek, California, USA. Data were collected in 2019 to determine the influence of burns conducted between 1999 and 2011 on vegetation, forest structure, and fuel load

\begin{tabular}{|c|c|c|c|c|c|}
\hline \multirow{2}{*}{$\begin{array}{l}\text { Fuel } \\
\text { variable }\end{array}$} & \multicolumn{2}{|c|}{ Mean loading (SE) } & \multicolumn{3}{|c|}{ ANOVA results } \\
\hline & Unburned & Burned & $F$ & $P$ & df \\
\hline uff depth (cm) & $7.47(0.22)$ & $3.75(0.15)$ & 198.11 & $<0.0010$ & 1 \\
\hline Litter depth (cm) & $5.23(0.18)$ & $4.61(0.15)$ & 4.67 & 0.031 & 1 \\
\hline Fuel depth (cm) & $10.1(1.18)$ & $10.83(1.20)$ & 1.073 & 0.30 & 1 \\
\hline FWF $\left(\mathrm{Mg} \mathrm{ha}^{-1}\right)$ & $6.11(0.4)$ & $6.39(0.42)$ & 0.095 & 0.76 & 1 \\
\hline CWF $\left(\mathrm{Mg} \mathrm{ha}^{-1}\right)$ & $122.56(26.67)$ & $71.92(19.44)$ & 5.035 & 0.026 & 1 \\
\hline
\end{tabular}

No significant differences were noted in total basal area $\left(\mathrm{m}^{2} \mathrm{ha}^{-1}\right)$ of all tree species combined between burned and unburned sites (Table 5). Additionally, basal dominance of $N$. densiflorus, S. sempervirens, Quercus spp., Arbutus menziesii Pursh, and P. menziesii var. menziesii showed no statistically significant differences between burned and unburned locations based on nested ANOVA results.

\section{Understory plant composition}

While no trends were noted between time since fire and total understory cover and richness, Spearman's correlation analysis did indicate positive rank order correlations between woody shrub species richness and percent cover (Table 2). In addition, nested ANOVA tests indicated significant differences in shrub percent cover per plot and shrub species richness per plot between burned and unburned plots $(F=22.85, P<0.001, \mathrm{df}=1$, and $F=9.81$, $P=0.0022, \mathrm{df}=1$, respectively). Burned plots exhibited both lower percent shrub cover per plot as well as lower shrub species richness per plot, compared to unburned plots (Table 6). No statistically significant differences were indicated for herbaceous understory species richness cover between burned and unburned sites based on nested ANOVA results, and no indication of an increase in non-native species was noted.

The presence of individual understory species appeared to be generally independent of treatment with 25 of the 38 species recorded found in both the burned and unburned treatments (Table 7). Most of the shrub species recorded were low in abundance, with Frangula californica (Eschsch.) A. Gray and Morella californica (Cham. \& Schltdl.) Wilbur found only on unburned sites, and

Table 4 Comparison of forest stand density (stems ha ${ }^{-1}$ ) of trees between burned $(n=60)$ and unburned $(n=60)$ plots in Big Basin Redwoods State Park, Boulder Creek, California, USA. Data were collected in 2019 to determine the influence of burns conducted between 1999 and 2011 on vegetation, forest structure, and fuel load. SESE = Sequoia sempervirens, NODE = Notholithocarpos densiflorus, PSME = Pseudotsuga menziesii, ARME = Arbutus menziesii, QU spp. = all Quercus species combined. Dashes (-) indicate insufficient sample size for analysis

\begin{tabular}{|c|c|c|c|c|c|}
\hline \multirow[b]{2}{*}{ Tree } & \multicolumn{2}{|c|}{ Mean density in stems $\mathrm{ha}^{-1}$ (SE) able 5} & \multicolumn{3}{|c|}{ Nested ANOVA results } \\
\hline & Unburned & Burned & $F$ & $P$ & df \\
\hline SESE $>10 \mathrm{~cm}$ & $207.96(22.03)$ & $205.84(19.63)$ & 0.0011 & 0.97 & 1 \\
\hline NODE $>10 \mathrm{~cm}$ & $216.45(21.89)$ & $114.59(18.08)$ & 15.36 & $<0.0010$ & 1 \\
\hline PSME $>10 \mathrm{~cm}$ & $42.44(10.75)$ & $31.83(10.77)$ & 0.99 & 0.32 & 1 \\
\hline QU spp. $>10 \mathrm{~cm}$ & $6.36(4.71)$ & $0.00(0.00)$ & 1.97 & 0.16 & 1 \\
\hline ARME $>10 \mathrm{~cm}$ & $0.00(0.00)$ & $4.24(4.24)$ & 1.00 & 0.32 & 1 \\
\hline All trees $>10 \mathrm{~cm}$ & $473.22(27.92)$ & $356.51(24.55)$ & 10.10 & 0.0019 & 1 \\
\hline SESE $<1 \mathrm{~m}$ & $3463.21(1075.94)$ & $2779.91(479.04)$ & 0.35 & 0.14 & 1 \\
\hline SESE $>1 \mathrm{~m}$ & $1239.29(677.52)$ & $1088.62(487.68)$ & 0.036 & 0.85 & 1 \\
\hline $\mathrm{NODE}<1 \mathrm{~m}$ & 6992.21 (989.13) & $4034.05(661.12)$ & 12.43 & $<0.0010$ & 1 \\
\hline NODE $>1 \mathrm{~m}$ & 3338.01 (337.62) & $823.36(127.34)$ & 61.37 & $<0.0010$ & 1 \\
\hline PSME <1 m & $10.61(6.27)$ & $36.08(13.57)$ & - & - & - \\
\hline PSME $>1 \mathrm{~m}$ & $10.61(6.96)$ & $27.59(15.46)$ & - & - & - \\
\hline QU spp. $<1$ m & $40.32(17.77)$ & $10.61(6.27)$ & - & - & - \\
\hline QU spp. $>1$ m & $4.24(2.98)$ & $0.00(0.00)$ & - & - & - \\
\hline ARME $<1 \mathrm{~m}$ & $0.00(0.00)$ & $8.49(8.49)$ & - & - & - \\
\hline ARME $>1 \mathrm{~m}$ & $0.00(0.00)$ & $0.00(0.00)$ & - & - & - \\
\hline All trees $<1 \mathrm{~m}$ & 10506.35 (1504.89) & $6869.13(745.38)$ & 5.98 & 0.016 & 1 \\
\hline All trees $>1 \mathrm{~m}$ & 4592.15 (683.72) & 1939.57 (505.91) & 30.88 & $<0.0010$ & 1 \\
\hline
\end{tabular}




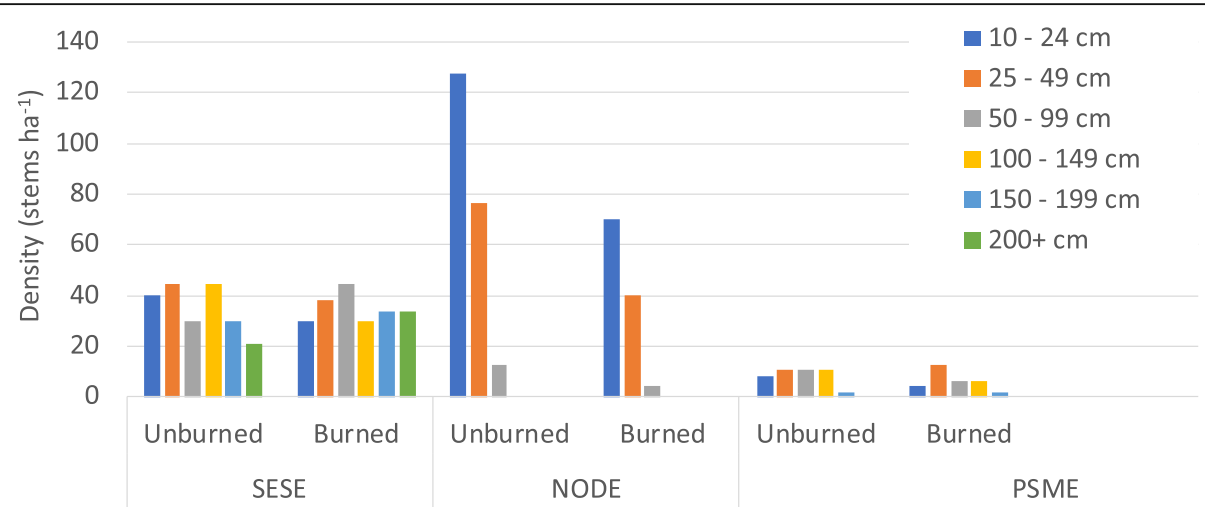

Fig. 3 Mature size class distribution of three dominant tree species, comparing burned and unburned treatments, in Big Basin Redwoods State Park, Boulder Creek, California, USA. Data were collected in 2019 to determine the influence of burns conducted between 1999 and 2011 on vegetation, forest structure, and fuel load. Within nested ANOVA tests, significant differences were noted exclusively within NODE in the 10 to 24 $\mathrm{cm}$ and 25 to $49 \mathrm{~cm}$ size classes. Species abbreviations are defined as follows: SESE = Sequoia sempervirens, NODE = Notholithocarpus densiflorus, PSME = Pseudotsuga menziesii

Symphoricarpos albus (L.) S. F. Blake found only on burned sites. Vaccinium ovatum Pursh, which was the most common shrub recorded across treatments, was more abundant in unburned versus burned plots. A similar pattern of distribution was noted for herbaceous understory species, with only Iris fernaldii R. C. Foster, Lysimachia latifolia (Hook.) Cholewa, and Polygala californica Nutt. recorded across all sample sites. The only non-native species identified was Epipactis helleborine (L.) Crantz, which was found in both burned and unburned treatments.
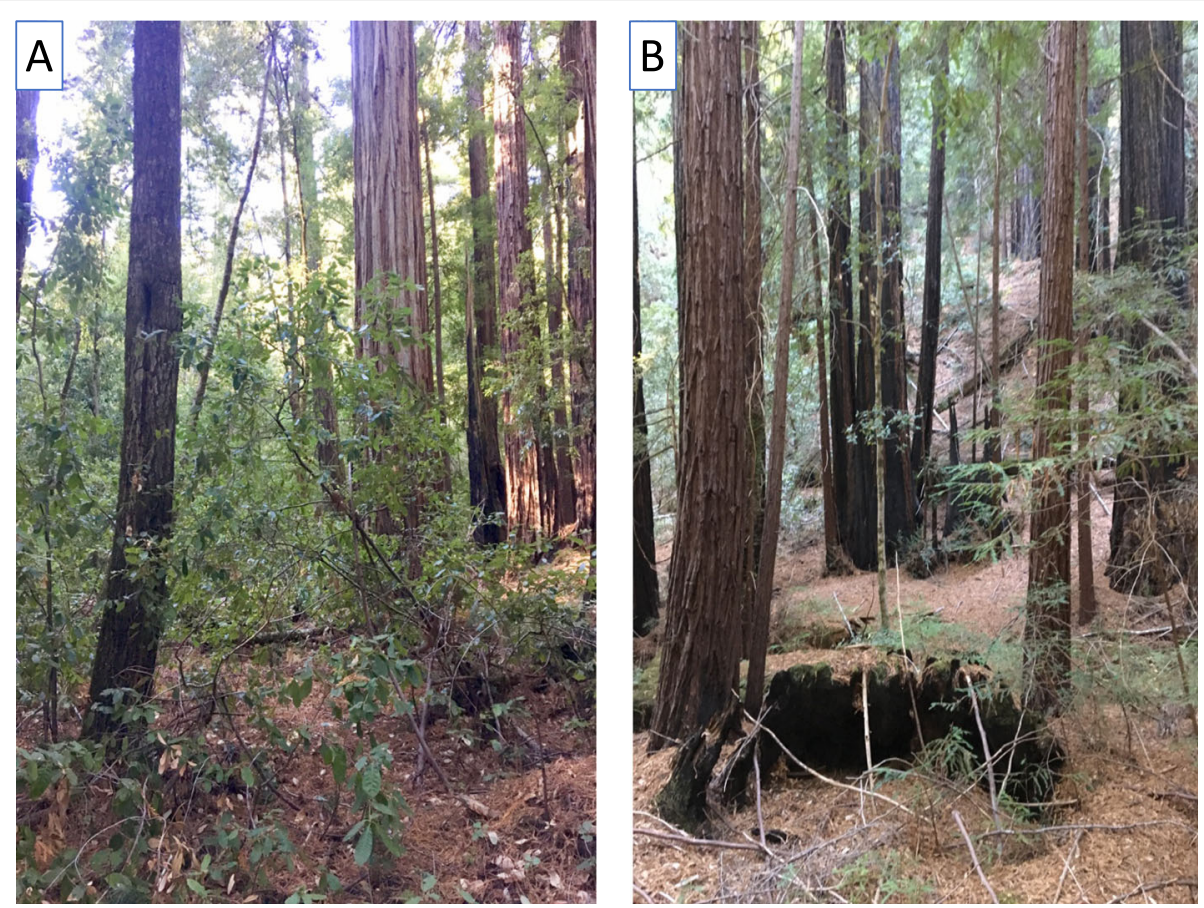

Fig. 4 Unburned and burned forest stand characteristics in Big Basin Redwoods State Park, Boulder Creek, California, USA. Data were collected in 2019 to determine the influence of burns conducted between 1999 and 2011 on vegetation, forest structure, and fuel load. The unburned image (A) is from the North Escape Road site (NERU), and the burned image (B) was from the 2011 Johansen Road East project (JREB). Images depict similar density and diameter distributions of Sequoia sempervirens and higher density of Notholithocarpos densiflorus in unburned sites. Photo credit: David Cowman, 2018 
Table 5 Comparison of relative mean basal dominance and basal area between burned $(n=60)$ and unburned $(n=60)$ plots in Big Basin Redwoods State Park, Boulder Creek, California, USA. Data were collected in 2019 to determine the influence of burns conducted between 1999 and 2011 on vegetation, forest structure, and fuel load. SESE = Sequoia sempervirens, NODE = Notholithocarpos densiflorus, PSME = Pseudotsuga menziesii, ARME = Arbutus menziesii, QU spp. = all Quercus species combined

\begin{tabular}{|c|c|c|c|c|c|}
\hline \multirow[b]{2}{*}{ Tree } & \multicolumn{2}{|c|}{ Relative mean basal area (SE) } & \multicolumn{3}{|c|}{ Nested ANOVA results } \\
\hline & Unburned & Burned & $F$ & $P$ & df \\
\hline SESE & $0.70(0.05)$ & $0.76(0.05)$ & 0.28 & 0.60 & 1 \\
\hline NODE & $0.17(0.04)$ & $0.12(0.04)$ & 3.58 & 0.061 & 1 \\
\hline PSME & $0.12(0.04)$ & $0.07(0.03)$ & 1.72 & 0.192 & 1 \\
\hline QU spp. & $0.00(0.00)$ & $0.00(0.00)$ & 1.81 & 0.18 & 1 \\
\hline ARME & $0.00(0.00)$ & $0.00(0.00)$ & 1.00 & 0.32 & 1 \\
\hline All trees basal area $\left(\mathrm{m}^{2} \mathrm{ha}^{-1}\right)$ & $282.58(29.66)$ & 314.79 (37.87) & 0.012 & 0.91 & 1 \\
\hline
\end{tabular}

\section{Discussion}

The management of fuels is of concern in old-growth $S$. sempervirens forests, as some of the highest fuel loads in any forest type have been recorded in coast redwood (Graham 2009). The results of this study indicated that prescribed fire was effective in reducing several measures of fuel load with no adverse impacts to associated understory species or increase in the abundance of non-natives species. Fuel load and fuel bed depth are known to influence the severity and rate of spread of fire (Nives 1979), and the reduction in fuel load, including coarse woody fuels, can limit the mortality for individual trees (Metz et al. 2011; Metz et al. 2013). The reduction of litter and duff depth were particularly important as S. Sempervirens produces the third most flammable litter of any coniferous species (Varner and Jules 2017), and excess duff can result in persistent smoldering around the base of live trees for some species, increasing mortality. In comparison, mechanical thinning treatments alone can increase, rather than decrease, the same measures, suggesting that prescribed fire is the preferred fuel mitigation option (Glebocki 2015). A lack of decline in fine woody fuel $(<7.6 \mathrm{~cm}$ diameter) load after fire was not surprising as fine woody fuels are known to reestablish quickly after burning. Engber et al. (2017), for example, noted a full recovery of fine surface fuels
7 yr after burning. As a result, subsequent burns may be required to limit the impact of post-fire sprouting.

A post-burn decline in the abundance of woody shrubs and $N$. densiflorus in the smaller size classes $(<10 \mathrm{~cm}$ $\mathrm{DBH},>1 \mathrm{~m}$ height) was noted. Prescribed fire also appeared to reduce the dominance and density of $N$. densiflorus, a result consistent with Ramage et al. (2010) and Lazzeri-Aerts and Russell (2014). However, variation in the density of $N$. densiflorus has also been noted as a result of gap phase dynamics, so that the extent that prescribed fire was a driver of this variation is not clear (Hunter and Parker 1993; Hunter et al. 1999). Burning had little effect on S. sempervirens stand density within any of the size classes, which is largely consistent with Engber et al. (2017), who found no shift in overstory tree composition following prescribed fire. These findings are also consistent with Lazzeri-Aerts and Russell (2014), who found $100 \%$ survivorship of S. sempervirens greater than $7.5 \mathrm{~cm} \mathrm{DBH}$ following fire.

In the woody shrub layer, the most drastic shift of species composition was in regard to cover of $\mathrm{Vac}$ cinium ovatum. Within coastal California, the majority of the $V$. ovatum native range has experienced infrequent fire intervals during pre-settlement times (Stuart 1987). Tirmenstein (1990) argued that this may have led to poorly developed adaptations to fire within the species. According to Martin (1979), V. ovatum

Table 6 Comparison of herbaceous and shrub species richness and diversity between burned $(n=60)$ and unburned ( $n=60)$ plots in Big Basin Redwoods State Park, Boulder Creek, California, USA. Data were collected in 2019 to determine the influence of burns conducted between 1999 and 2011 on vegetation, forest structure, and fuel load

\begin{tabular}{|c|c|c|c|c|c|}
\hline \multirow[b]{2}{*}{ Variable } & \multicolumn{2}{|l|}{ Mean (SE) } & \multicolumn{3}{|c|}{ Nested ANOVA results } \\
\hline & Unburned & Burned & $F$ & $P$ & df \\
\hline Understory richness (species per plot) & $1.8(0.2)$ & $2.1(0.2)$ & 0.37 & 0.55 & 1 \\
\hline Understory percent cover (per plot) & $2.9(0.7)$ & $7.3(1.9)$ & 4.00 & 0.050 & 1 \\
\hline Shrub richness (species per plot) & $1.2(0.1)$ & $0.7(0.1)$ & 22.85 & $<0.0010$ & 1 \\
\hline Shrub percent cover (per plot) & $9.6(2.0)$ & $1.6(0.5)$ & 9.81 & 0.0022 & 1 \\
\hline
\end{tabular}


Table 7 Mean cover (\%) of understory plant species found within six sample sites in Big Basin Redwoods State Park, Boulder Creek, California, USA. Data were collected in 2019 to determine the influence of burns conducted between 1999 and 2011 on vegetation, forest structure, and fuel load. Asterisk $\left(^{*}\right)$ denotes non-native species. Dashes (-) mean species not found

\begin{tabular}{|c|c|c|c|c|c|c|}
\hline \multirow[b]{3}{*}{ Species } & \multicolumn{6}{|c|}{ Mean cover (\%) } \\
\hline & \multicolumn{3}{|c|}{ Unburned } & \multicolumn{3}{|c|}{ Burned } \\
\hline & NERU & S2SU & SUNU & JREB & S2SB & OVSB \\
\hline \multicolumn{7}{|l|}{ Woody shrub species } \\
\hline Frangula californica & - & 0.03 & 0.03 & - & - & - \\
\hline Lonicera hispidula (Lindl.) Douglas ex Torr. \& A. Gray & 0.6 & 1.7 & 0.5 & 0.06 & 0.5 & 0.4 \\
\hline Morella californica & - & 0.6 & - & - & - & - \\
\hline Rosa gymnocarpa Nutt. & - & - & 0.1 & - & 0.1 & - \\
\hline Rubus ursinus Cham. \& Schltdl. & 0.4 & - & - & 0.05 & - & - \\
\hline Symphoricarpos albus & - & - & - & - & 0.03 & - \\
\hline Symphoricarpos mollis Nutt. & - & 0.03 & - & - & - & - \\
\hline Toxicodendron diversilobum (Torr. \& A. Gray) Greene & 0.09 & 0.01 & - & 0.05 & - & - \\
\hline Vaccinium ovatum & 4.5 & 19.8 & 0.1 & 0.7 & - & 1.4 \\
\hline Whipplea modesta Torr. & - & 0.4 & - & 0.9 & 0.5 & 0.09 \\
\hline \multicolumn{7}{|l|}{ Herbaceous species } \\
\hline Asarum caudatum Lindl. & - & - & - & - & 0.02 & - \\
\hline Bromus Scop. sp. & 0.006 & 0.01 & - & - & 0.4 & 0.006 \\
\hline Calamagrostis rubescens Buckley & - & - & 0.2 & - & - & 0.7 \\
\hline Carex globosa Boott & 0.006 & 0.3 & - & 0.4 & 1.6 & - \\
\hline Carex L. sp. & - & - & - & - & 1.2 & 0.9 \\
\hline Carex tumulicola Mack. & - & - & - & - & 0.2 & - \\
\hline Dryopteris arguta (Kaulf.) Maxon & 0.05 & 0.04 & 0.4 & - & - & - \\
\hline Epipactis helleborine * & 0.03 & - & 0.04 & 0.2 & 0.01 & - \\
\hline Equisetum arvense L. & - & - & - & 0.01 & - & - \\
\hline Festuca occidentalis Hook. & - & - & - & - & 0.03 & - \\
\hline Galium californicum Hook. \& Arn. & 1.08 & 0.02 & - & 0.03 & 0.02 & - \\
\hline Iris douglasiana Herb. & - & - & 0.4 & - & - & - \\
\hline Iris fernaldii & 0.2 & 0.09 & 0.1 & 0.2 & 0.1 & 0.3 \\
\hline Lysimachia latifolia & 0.04 & 0.2 & 0.05 & 0.1 & 0.9 & 0.4 \\
\hline Maianthemum racemosum (L.) LInk & 0.03 & - & - & - & 0.06 & 0.003 \\
\hline Maianthemum stellatum (L.) LInk & 0.03 & - & - & - & - & - \\
\hline Oxalis oregana Nutt. & 0.5 & 0.4 & 3.06 & 0.2 & 12.5 & - \\
\hline Pityrogramma triangularis (Kaulf.) Yatsk., Windham \& E. Wollenw. & - & - & - & 0.003 & - & - \\
\hline Polygala californica Nutt. & 0.2 & 0.09 & 0.1 & 0.02 & 0.1 & 0.1 \\
\hline Polypodium californicum Kaulf. & 0.06 & - & 0.006 & - & - & - \\
\hline Polystichum munitum (Kaulf.) C. Presl & 0.1 & 0.04 & 0.5 & 0.02 & 0.04 & - \\
\hline Prosartes hookeri Torr. & - & 0.01 & 0.06 & - & 0.1 & 0.08 \\
\hline Pteridium aquilinum (L.) Kuhn var. pubescens Underw. & - & 0.03 & - & - & 0.006 & - \\
\hline Stachys bullata Benth. & - & 0.04 & - & 0.05 & 0.03 & - \\
\hline Trillium ovatum Pursh & 0.1 & 0.01 & 0.03 & - & 0.04 & 0.01 \\
\hline Vicia americana ssp. americana Willd. & 0.05 & 0.04 & - & 0.01 & - & - \\
\hline Viola ocellata Torr. \& A. Gray & 0.01 & - & 0.01 & - & 0.08 & 0.2 \\
\hline Viola sempervirens Greene & - & - & 0.05 & 0.01 & 0.08 & - \\
\hline
\end{tabular}


rarely reproduces via seed dispersal and has a seed bank and sub-surface root structure prone to mortality in the presence of duff-consuming surface fires with a long residence time. These factors, coupled with the timing of prescribed fires in this study, during the late fall and early winter months when live fuel moisture is low, could explain the lower presence and cover of $V$. ovatum in burned treatment plots.

Although a marginal difference was found in canopy cover between burned and unburned plots, there was no difference in tree species composition or structure of $S$. sempervirens. The difference in mean canopy cover between burned and unburned plots represented less than a $3 \%$ shift and was due to a reduction in the subcanopy layer of hardwood and juvenile tree species, rather than the creation of forest canopy gaps. And while changes in crown fuels were not measured directly, reduction in ladder fuels suggests a disruption of vertical-fuel continuity in these stands and a potential decline in crown-fire potential (Scott 2001; Cruz et al. 2004).

The absence of shifts in understory herbaceous plant composition following burning was encouraging. Mechanical fuel reduction can have adverse impacts on the S. sempervirens-associated herbaceous species and can provide opportunities for the invasion of non-native species (Loya and Jules 2008; Blair et al. 2010; Russell and Michels 2010; Hanover and Russell 2018). Intentional burning, at least in this case, did not appear to have negative impacts on herbaceous understory species.

\section{Conclusions}

Prescribed fire in the southern extent of the S. sempervirens range has the potential to reduce fuel load while maintaining understory diversity and native species' assemblages. Positive correlations noted between similar variables and time since burn indicated that, in the absence of fire, $S$. sempervirens forest trends toward higher fuel load and less fire-tolerant characteristics. With a host of adaptations to disturbance and a relative lack of vulnerability to non-native species establishment, the $S$. sempervirens ecosystem is an ideal candidate for satisfying fuel reduction goals while maintaining ecological integrity. Evidence points to higher fire return intervals in S. sempervirens ecosystems with proximity to adjacent grasslands, shrublands, and oak woodlands (Greenlee and Langenheim 1990). Progressing forward into an uncertain climatic future, a crucial aspect of forest management will be satisfying fuel management goals while minimizing adverse ecological impacts, and creating more firetolerant ecosystems.

\section{Acknowledgements}

The California State Parks Natural Resource Management Program in the Santa Cruz District provided a scientific collection permit for Big Basin Redwoods State Park as well as funding, expertise, and invaluable resources for this project. Specifically, we would like to thank district environmental scientists J. Kerbavaz, T. Hyland, P. Halbert, and T. Reilly. In addition, The Kiwanis Club of West San Jose provided funding for this project through the Luckhardt Kiwanis scholarship. We would also like to thank Dr. C. Dicus from Cal Poly San Luis Obispo for help with fuel load calculations, and A. Jones from the University of California, Santa Cruz, Upper Campus Natural Reserve for assistance with data collection methodology. Finally, we thank A. Bonilla, K. McFadden, and B. Patterson for data collection assistance on this project.

\section{Authors' contributions}

DC and WR contributed to the design of the study as well as preparation of the manuscript. DC collected all field data and performed data analysis. DC and WR read and approved the final manuscript.

\section{Funding}

This project was funded by the California State Parks Natural Resource Management Program in the Santa Cruz District, as well as a John Luckhardt scholarship administered by the Kiwanis Club of West San Jose.

\section{Availability of data and materials}

The datasets used or analyzed during the current study area available from WR on reasonable request.

\section{Declarations}

Ethics approval and consent to participate

Not applicable.

\section{Consent for publication}

Not applicable.

\section{Competing interests}

The authors declare that they have no competing interests.

\section{Author details}

${ }^{1}$ California State Department of Parks and Recreation, 303 Big Trees Park Road, Felton, California 95018, USA. ${ }^{2}$ Department of Environmental Studies, San Jose State University, One Washington Square, San Jose, California 95192, USA.

Received: 23 April 2020 Accepted: 25 February 2021

Published online: 26 May 2021

\section{References}

Baldwin, B.G., D.H. Goldman, D.J. Kell, R. Patterson, and T.J. Rosatti, eds. 2012. The Jepson Manual: Vascular Plants of California, Second. Berkeley, California, USA: University of California Press https://doi.org/10.1525/9780520951372.

Barbour, M.S., M. Lydon, M. Borchert, V. Popper, V. Whitworth, and J. Evarts. 2001. Coast Redwood: a Natural and Cultural History. Los Olivos: Cachuma Press.

Biswell, H. 1989. Prescribed Burning in California Wildlands Vegetation Management Berkeley: University of California Press.

Blair, B.C., D.K. Letorneou, S.G. Bothwell, and G.F. Hayes. 2010. Disturbance, resources, and exotic plant invasion: gap size effects in a redwood forest. Madroño 57: 11-19 https://doi.org/10.3120/0024-9637-57.1.11.

Brooks, M.L., C.M. D'Antonio, D.M. Richardson, B. James, J.E. Keeley, J.M. Ditomaso, R.J. Hobbs, M. Pellant, and D. Pyke. 2004. Effects of invasive alien plants on fire regimes. Bioscience 54: 677-688 https://doi.org/10.1641/0006-3568(2004 054[0677:eoiapo]2.0.co;2.

Brower, J.E., J.H. Zar, and C. Von Ende. 1998. Field and Laboratory Methods for General Ecology. Boston: WCB/McGraw-Hill.

Brown, J.K. 1974. Handbook for inventorying downed woody material. USDA Forest Service. General Technical Report INT-GTR-16. Ogden: USDA Forest Service, Intermountain forest and Range Experiment Station https://www.fs.fed.us/ rm/pubs_int/int_gtr016.pdf.

Busing, R.T., and T. Fujimori. 2002. Dynamics of composition and structure in an old Sequoia sempervirens forest. Journal of Vegetation Science 13: 785-792 https://doi.org/10.1111/j.1654-1103.2002.tb02108.x. 
Cruz, M.G., M.E. Alexander, and R.H. Wakimoto. 2004. Modeling the likelihood of crown fire occurrence in conifer forest stands. Forest Science 50: 640-658 https://doi.org/10.1071/wf16218.

D'Antonio, C.M., and P. Vitousek. 1992. Biological invasions by exotic grasses, the grass/fire cycle, and global change. Annual Review of Ecology and Systematics 23: 63-87 https://doi.org/10.1146/annurev.es.23.110192.000431.

Engber, E., J. Teraoka, and P. van Mantgem. 2017. Forest restoration at Redwood national park. Exploring prescribed fire alternatives to second growth management: a case study. Paper presented at Coast Redwood Science Symposium, Eureka, CA, Aug 16, 2016. https://www.fs.fed.us/psw/publica tions/documents/psw_gtr258/psw_gtr258_075.pdf.

Finney, M.A., and R.E. Martin. 1993. Fuel loading, bulk density, and depth of forest floor in coast redwood stands. Forest Science 39: 617-622.

Fligner, M.A., and T.J. Killeen. 1976. Distribution-free two-sample tests for scale. Journal of the American Statistical Association 71: 210-213 https://doi.org/10.1 080/01621459.1976.10481517.

Glebocki, R. 2015. Fuel loading and moisture dynamics in thinned coast redwood Douglas-fir forests in Headwaters Forest Reserve, California, Thesis. Arcata: Humboldt State University.

Graham, B.D. 2009. Structure of downed woody and vegetative detritus in oldgrowth Sequoia sempervirens forests. MS Thesis. Arcata, California: Humboldt State University.

Greenlee, J.M., and J.H. Langenheim. 1990. Historic fire regimes and their relation to vegetation patterns in the Monterey Bay area of California. American Midland Naturalist 124: 239-253 https://doi.org/10.2307/2426173.

Hanover, A., and W. Russell. 2018. Understory recovery in coast redwood communities: A case study comparing a naturally recovering and actively managed forest. Open Journal of Forestry 8: 489-499 https://doi.org/10.4236/ojf.2018.84031.

Hunter, J.C., and V.T. Parker. 1993. The disturbance regime of an old-growth forest in coastal California. Journal of Vegetation Science 4: 9-24 https://doi. org/10.2307/3235729.

Hunter, J.C., V.T. Parker, and M.G. Barbour. 1999. Understory light and gap dynamics in an old-growth forested watershed in coastal California. Madrono 46: 1-6.

Jones, C., and W. Russell. 2001. The effects of timber harvesting on the structure and composition of adjacent old-growth coast redwood forest, California, USA. Landscape Ecology 16: 731-741 https://www.springer.com/journal/1 0980. https://doi.org/10.1023/A:1014486030462.

Jones, G.A., and W. Russell. 2015. Approximation of fire-return intervals with point samples in the southern range of the coast redwood forest, California, USA. Fire Ecology 3: 80-94 https://doi.org/10.4996/fireecology.1103080.

Keeley, J.E. 2002. Native American impacts on fire regimes of the California coastal ranges. J Biogeography 29: 303-320 https://doi.org/10.1046/j.1365-2 699.2002.00676.x

Keeley, J.E. 2005. Fire history of the San Francisco Bay region and implications for landscape patterns. International Journal of Wildland Fire 14: 285-296 https:// doi.org/10.1071/WF05003.

Keyes, C.R., and J.M. Varner. 2006. Pitfalls in the silvicultural treatment of canopy fuels. Fire Management Today 66: 46-50 https://www.fs.usda.gov/managing-la nd/fire/fire-management-today.

Korhonen, L., K.T. Korhoren, M. Rautiainen, and P. Stenberg. 2006. Estimation of forest canopy cover: a comparison of field measurement techniques. Silva Fennica 4: 577-588 https://doi.org/10.14214/sf.315.

Laird, N., and D.M. Bates. 1988. Random-effects models for longitudinal data. Biometrics 38: 963-974 https://doi.org/10.2307/2529876.

Lazzeri-Aerts, R., and W. Russell. 2014. Survival and recovery following wildfire in the southern range of the coast redwood forest. Fire Ecology 10: 43-55 https://doi.org/10.4996/fireecology.1001043.

Lorimer, Craig G., Daniel J. Porter, Mary Ann Madej, John D. Stuart, Stephen D. Veirs Jr., Steven P. Norman, Kevin L. O'Hara, and William J. Libby. 2009. Presettlement and modern disturbance regimes in coast redwood forests: Implications for the conservation of old-growth stands. Forest Ecology and Management 258: 1038-1054 https://doi.org/10.1016/j.foreco.2009.07.008.

Loya, D.T., and E.S. Jules. 2008. Use of species richness estimators improves evaluation of understory plant response to logging: a study of redwood forests. Plant Ecology 194: 179-194 https://doi.org/10.1007/s11258-007-9283-z.

Mack, M.C., and C.M. D'Antonio. 1998. Impacts of biological invasions on disturbance regimes. Trends in Ecology and Evolution 13: 195 https://doi.org/1 0.1016/s0169-5347(97)01286-x.

Martin, P. 1979. Productivity and taxonomy of the Vaccinium globulare, V. membranaceum complex in western Montana. Thesis. Missoula: University of Montana.
Martin, R.W. 1998. Meteorology: Big Basin Redwoods State Park. Sacramento: California Department of Parks and Recreation, Northern Service Center https://www.parks.ca.gov/pages/21299/files/bbplant.pdf.

McBride, J.R. 1983. Analysis of tree-rings and fire scars to establish fire history. Tree-Ring Bulletin 43: 51-68.

McCune, B., and J.B. Grace. 2002. Analysis of Ecological Communities. 3rd ed. Gleneden Beach: MJM Software Design.

Metz, M.R., K.M. Frangioso, R.K. Meentemeyer, and D.M. Rizzo. 2011. Interacting disturbances: wildfire severity affected by stage of forest disease invasion. Ecological Applications 21: 313-320 https://doi.org/10.1890/10-0419.1.

Metz, M.R., J.M. Varner, K.M. Frangioso, R.K. Meentemeyer, and D.M. Rizzo. 2013. Unexpected redwood mortality from synergies between wildfire and an emerging infectious disease. Ecology 94: 2152-2159 https://doi.org/10.1890/13-0915.1.

Nives, S.L. 1979. Fire behavior on the forest floor in coastal redwood forest, Redwood National Park. Thesis. Arcata: Humboldt State University.

Norman, S.P., J.M. Varner, L. Arguello, S. Underwood, B. Graham, G. Jennings, Y. Valachovic, and C. Lee. 2009. Fire and fuels management in coast redwood forests. JFSP Research Project Reports 158 https://digitalcommons.unl.edu/cgi/ viewcontent.cgi?article $=1156 \&$ context $=$ jfspresearch .

Ramage, B. S., K. L. O'Hara. \& B. T. Caldwell, (2010). The role of fire in the competitive dynamics of coast redwood forests. Ecosphere 1:1-18. https:// doi.org/10.1890/ES10-00134.1.

Reid, M., and S. Thompson. 1996. Ecological fieldwork methods. In Essential Environmental Science: Methods and Techniques, ed. S. Watts and L. Halliwell, 357-388. London: Routledge Press.

R Development Core Team. 2017. R: a language and environment for statistical computing. R Foundation for Statistical Computing, Vienna, Austria. https:// www.R-project.org/.

Russell, W., and K.H. Michels. 2010. Stand development on a 127-yr chronosequence of naturally regenerating Sequoia sempervirens (Taxodiaceae) forests. Madroño 57: 229-241 https://doi.org/10.3120/0024-9637-57.4.229.

Scherer, S.S., A.W. D'Amato, C.C. Kern, B.J. Palik, and M.B. Russell. 2016. Long-term impacts of prescribed fire on stand structure, growth, mortality, and individual tree vigor in Pinus resinosa forests. Forest Ecology and Management 368: 7-16 https://doi.org/10.1016/j.foreco.2016.02.038.

Scott, J.H. 2001. Assessing crown fire potential by linking models of surface and crown fire behavior (No. 29). US Department of Agriculture, Forest Service, Rocky Mountain Research Station https://doi.org/10.2737/RMRS-RP-29.

Srivastava, M.S., and T.K. Hui. 1987. On assessing multivariate normality based on Shapiro-Wilk W statistic. Statistics \& Probability Letters 5: 15-18 https://doi. org/10.1016/0167-7152(87)90019-8.

Stephens, S.L., and D.L. Fry. 2005. Fire history in coast redwood stands in the northeastern Santa Cruz mountains, California. Fire Ecology 1: 2-19 https:// doi.org/10.4996/fireecology.0101002.

Stephens, S.L., J.M. Kane, and J.D. Stuart. 2018. North Coast Bioregion. In Fire in California's Ecosystems, ed. J. van Wagtendonk and N. Sugihara, 146-169. Berkeley, California: University of California Press.

Stuart, J.D. 1987. Fire history of an old-growth forest of Sequoia sempervirens (taxodiaceae) forest in Humboldt Redwoods State Park, California. Madrono 34: 128-141 https://www.jstor.org/stable/41424623.

Tirmenstein, D. 1990. Vaccinium ovatum. In Fire Effects Information System. Fort Collins: USDA Forest Service, Rocky Mountain Research Station, Fire Sciences Laboratory https://www.fs.fed.us/database/feis/plants/shrub/vacova/all.html.

Varner, J.M. and E.S. Jules. 2017. The enigmatic fire regime of coast redwood forests and why it matters. Gen. Tech. Rep. PSW-GTR-258. Albany, CA: US Department of Agriculture, Forest Service, Pacific Southwest Research Station: 15-18, 258, pp. 15-18.

Varner, J.M., H.G. Kuljian, and , J.K. Kreye. 2017. Fires without tanoak: the effects of a non-native disease on future community flammability. Biological Invasions 19:2307-2317. https://doi.org/10.1007/s10530-017-1443-z

\section{Publisher's Note}

Springer Nature remains neutral with regard to jurisdictional claims in published maps and institutional affiliations. 